\title{
Artificial light improves size selection for northern shrimp (Pandalus borealis) in trawls
}

\author{
Ólafur Arnar Ingólfsson, Terje Jørgensen, Manu Sistiaga, and Liz Kvalvik
}

\begin{abstract}
Size selection in the northern shrimp (Pandalus borealis) trawl fisheries is a widely studied topic. While the focus has largely been on codend and grid selectivity, studies have shown the importance of other design changes and the application of artificial light to evoke behavioural responses. LED lights of three different colours — green $(\sim 470-580 \mathrm{~nm})$, white $(\sim 425-750 \mathrm{~nm})$ and red ( 580-670 $\mathrm{nm})$ - were mounted in the belly section of a shrimp trawl to investigate their influence on the overall selectivity of the trawl. The study was conducted using a twin-trawl setup, one with light and the other without light. For catch-comparison analysis, a polynomial regression with random effects was applied. The number of valid hauls with green, white and red lights were eleven, eight, and nine, respectively. All lights tested significantly affected the length-dependent retention of shrimp. Green light had the greatest effect, red the least. Significant loss was observed for shrimp below $17.5 \mathrm{~mm}$ carapace length (CL) for green light, $19.5 \mathrm{~mm}$ CL for white and $20.8 \mathrm{~mm}$ CL for red light.
\end{abstract}

Résumé : La sélection selon la taille dans les pêches au chalut à la crevette nordique (Pandalus borealis) a fait l'objet de nombreuses études. Si ces études portaient en bonne partie sur la sélectivité du cul de chalut et de la maille, certaines ont fait ressortir l'importance d'autres modifications à leur conception et de l'utilisation de lumière artificielle pour induire des réactions comportementales. Des lumières DEL de trois couleurs différentes - verte ( $\sim 470-580 \mathrm{~nm})$, blanche ( 425-750 nm) et rouge ( 580-670 nm) — ont été installées dans le ventre d'un chalut à crevettes afin d'examiner leur influence sur la sélectivité globale du chalut. Une configuration à chaluts jumeaux, un avec de la lumière et l'autre, sans, a été utilisée pour l'étude. Pour l'analyse comparative des prises, une régression polynomiale avec effets aléatoires a été appliquée. Le nombre de traits valides obtenus avec des lumières vertes, blanches et rouges s'élevait à onze, huit et neuf, respectivement. Toutes les lumières testées ont eu un effet significatif sur la rétention dépendante de la longueur de crevettes. La lumière verte a eu l'effet le plus important, et la lumière rouge, le moins grand effet. Des pertes significatives ont été observées pour les crevettes de longueur de carapace (LC) inférieure à $17,5 \mathrm{~mm}$ LC pour la lumière verte, inférieure à $19,5 \mathrm{~mm}$ LC pour la lumière blanche et inférieure à $20,8 \mathrm{~mm} \mathrm{LC}$ pour la lumière rouge. [Traduit par la Rédaction]

\section{Introduction}

Shrimp fisheries are important worldwide, and harvesting is mostly done using trawls (Gillett 2008). In general, shrimp fisheries are regarded as poorly selective and frequently associated with excessive bycatch of other species (Kelleher 2005; Gillett 2008). The northern shrimp (Pandalus borealis) fisheries are no exception. In many areas, the issue of fish bycatch has to a large extent been remedied by the introduction of sorting grids like the Nordmøregrid (Isaksen et al. 1992; Garcia 2007). However, important issues remain regarding excessive catches of undersized shrimp, and bycatches of juveniles and small-sized teleost species.

The northern shrimp fishery in Skagerrak and the North Sea is not exempt from these problems. In this fishery, a 19-mm bar spacing Nordmøre-grid is mandatory to use, as well as a codend with a minimum mesh size of $35 \mathrm{~mm}$. As most of the shrimp pass through the grid, the selectivity of undersized shrimp is based on the selective properties of the codend. Shrimp vessels operating in Skagerrak and the North Sea grade their shrimp catch onboard into three categories: undersized shrimp $(<15 \mathrm{~mm}$ carapace length, CL), industrial shrimp $(\geq 15$ and $<20 \mathrm{~mm} \mathrm{CL})$, and boiled shrimp ( $\geq 20 \mathrm{~mm} \mathrm{CL}$ ). Although there is a landing obligation for all shrimp caught, including the undersized shrimp, the prices for boiled shrimp can be over 5 times higher than those for the industrial shrimp, which in turn implies risk for discards and high grading. Therefore, technical measures to reduce catches of the smallest shrimp are sought — both for economic and conservational reasons. In the Norwegian waters of Skagerrak and the North Sea, the minimum legal total length of shrimp is $6.5 \mathrm{~cm}$ (approximately $15 \mathrm{~mm} \mathrm{CL}$ ), and real-time closures are enforced in areas where numbers of undersized shrimp exceed $15 \%$ of the total catch (Anonymous 2005).

Most of the research carried out in shrimp fisheries has focused on reducing the bycatch of juvenile fish, either by changing the grid section or altering codend configuration (e.g., Campos et al. 2002; Broadhurst et al. 2004; Grimaldo 2006; Larsen et al. 2018a). In addition, attempts have been made to reduce catches of undersized shrimp by for example, adding low-bar-spacing grids to the main sorting grid design (He and Balzano 2007; Larsen et al. 2018b) or modifying the meshes in the codend (Thorsteinsson 1992). However, despite the positive contribution of these measures, the results reported show that they do not entirely solve the problem.

Studies have shown that shrimp selection can occur in the trawl body, long before the shrimp reach the aft part of the trawl gear (High et al. 1969; Thorsteinsson 1981; Polet 2000; Broadhurst

Received 3 December 2020. Accepted 2 June 2021.

Ó.A. Ingólfsson,* T. Jørgensen,* M. Sistiaga, and L. Kvalvik. Institute of Marine Research, P.O. Box 1870 Nordnes, N-5817 Bergen, Norway.

Corresponding author: Ólafur Arnar Ingólfsson (email: olafur.arnar.ingolfsson@hi.no).

${ }^{*}$ Equal authorship.

() 2021 Institute of Marine Research. This work is licensed under a Creative Commons Attribution 4.0 International License (CC BY 4.0), which permits unrestricted use, distribution, and reproduction in any medium, provided the original author(s) and source are credited. 
Fig. 1. Trawl and placement of lights. Two identical trawls were towed simultaneously, light colour varied and the lights were interchanged between the trawls. Assuming 30\% lateral mesh opening and circular shape of the transect, the vertical distance from the light to the bottom panel is $3.4 \mathrm{~m}$.

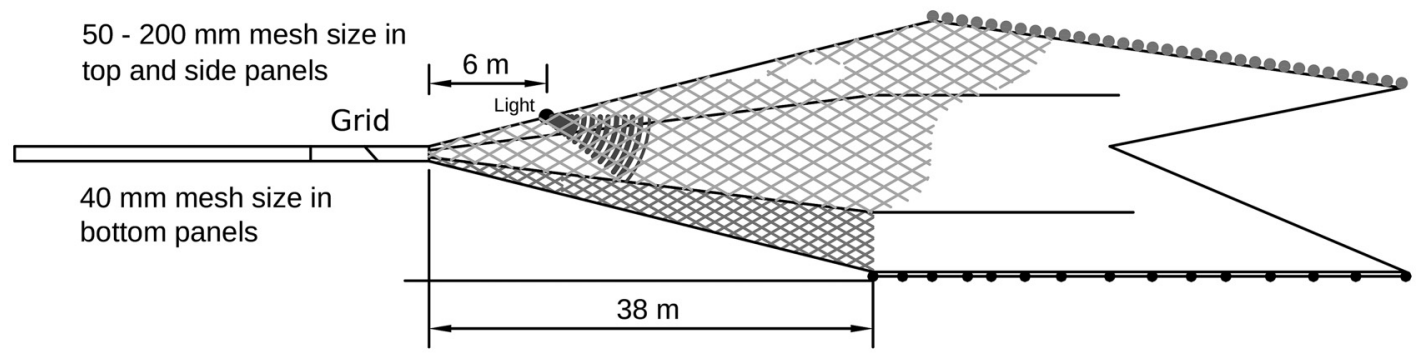

et al. 2012), and that ambient light level affects penaeid shrimp selection (Broadhurst et al. 2015). Conolly (1993) reported that shortening the belly of the trawl and consequently increasing the mesh openings and angle of attack of the netting panels, significantly reduced the bycatch of juvenile fish in the Brazilian shrimp fishery. More recently, Ingólfsson and Jørgensen (2020) documented a significant reduction in the catches of undersized shrimp in the Norwegian northern shrimp fishery by using a shortbelly trawl.

The use of light to reduce catches of unwanted species has gained interest in different fisheries in the last years (Nguyen and Winger 2019; Southworth et al. 2020). Shrimp have been believed to show limited behavioural response to the various trawl components during the capture phase (High et al. 1969; Wardle 1993; Hannah and Jones 2003). Therefore, most studies carried out with light in shrimp trawl fisheries have focused on the reduction of fish bycatch rather than the potential for alterations in the exploitation pattern of shrimp. Studies have shown that it is possible to influence fish behaviour and reduce the bycatch of certain species by placing lights at different positions in a shrimp trawl (e.g., Hannah et al. 2015). Research with lights have been carried out in other areas like the Barents Sea northern shrimp fishery, although with more varying results (Larsen et al. 2017).

The vision and spectral sensitivity of northern shrimp that inhabit environments with low light intensities has not been much studied. Eaton and Boyd (1970) and Eaton (1972) concluded that the spectral sensitivity of northern shrimp peaked around $500 \mathrm{~nm}$ (510 nm for males with carapace lengths below $20 \mathrm{~mm}$ ). More recently, Frank et al. (2012) investigated the spectral sensitivity of several deep-water crustaceans including two shrimp species, Heterocarpus ensifer and Euganotonotus crassus. Similar to the results of Eaton and Boyd (1970), their results also showed that the spectral sensitivity peaked at around $500 \mathrm{~nm}$ with a sensitive range of approximately $400-600 \mathrm{~nm}$. Six other crustacean species included in the study by Frank et al. (2012) also showed sensitivities in the same range. It is thus reasonable to assume that northern shrimp would be able to see light of different colours and would be particularly sensitive to green light.

An animal's sensory system is vital for its survival. Vision plays a role in, e.g., orientation, food search and predator avoidance (Cronin and Douglas 2014). Therefore, when attempting to exploit animals' senses to achieve size- and species selection in fisheries, care should be taken not to harm the sensory systems of the specimens that avoid capture. The long-term damaging effect of bright light on the crustacean eye depends on the ambient light intensity and the adaptational state to which the animals had been adjusted (Gaten 1988). The degree of light-induced crustacean photoreceptor damage depends on a number of variables, but once manifested, damage tends to be progressive and irreversible (Meyer-Rochow 2001). When exposed to white light with an intensity of $0.47 \mathrm{~W} \cdot \mathrm{m}^{-2}$ for $10 \mathrm{~min}$, some damage of the retinula cells of the deep-waterliving crustacean Cirolana borealis were observed, but the cells had recovered after $12 \mathrm{~h}$. At greater intensities $\left(4.9\right.$ to $\left.>70 \mathrm{~W} \cdot \mathrm{m}^{-2}\right)$, the damages were greater and recovery poor (Nilsson and Lindström 1983). Studies on dark-adapted Nephrops norvegicus show that $15 \mathrm{~s}$ exposure to dim daylight of $5.5 \mathrm{~W} \cdot \mathrm{m}^{-2}$ intensity can cause substantial damage (Shelton et al. 1985). After 5 min exposure, the destruction was almost total. In the absence of direct studies on light-induced damage on the eyes of northern shrimp, results from studies on other crustaceans indicate that light intensity should, for precautionary reasons, be kept at low levels and preferably for short periods.

Recent sea trials carried out in Skagerrak by the Norwegian Institute of Marine Research (IMR, unpublished data), showed that the size distribution of shrimp varied between eight standard hauls and three hauls where red (635 nm peak) lights were used to film in the belly section of the trawl. These observations led to the hypothesis that lights could be used to stimulate escape behaviour of shrimp through trawl meshes. The aim of the present study was thus to investigate whether lights of different colours, including the red light in the aforenamed trials by IMR, could be used to stimulate escape behaviour of northern shrimp in the belly section of a trawl.

\section{Materials and methods}

\section{Vessel, gear and data collection}

To test the effect of light on the size selectivity of shrimp, comparative sea trials were conducted off the coast of Norway (in Skagerrak) onboard the commercial shrimp trawler Tempo $(27.4 \mathrm{~m}$ length overall and $745 \mathrm{~kW}$ main engine) between 17 November and 6 December 2017.

Two trawls, both identical to the four-panel short belly trawl used by Ingólfsson and Jørgensen (2020), were towed simultaneously. The reason for using short trawls was to ensure mesh openness and facilitate shrimp size selection with the light stimuli. The upper and side panels of the $59.5 \mathrm{~m}$ long trawl bellies were built of netting with meshes that decreased from $200 \mathrm{~mm}$ nominal mesh length in front to $50 \mathrm{~mm}$ in the rearmost panels $(8 \mathrm{~m}$ $200 \mathrm{~mm}, 12 \mathrm{~m} 120 \mathrm{~mm}, 12 \mathrm{~m} 60 \mathrm{~mm}$ and $27.5 \mathrm{~m} 50 \mathrm{~mm}$ ). The bottom panels and codends had a mesh size of $40 \mathrm{~mm}$. A pair of Thyborøn trawl doors (2500 kg and $16 \mathrm{~m}^{2}$ each) and a $3000 \mathrm{~kg}$ centre weight were linked to the trawls by $53 \mathrm{~m}$ long bridles. In each of the trawls, a Nordmøre-grid $(1 \times 1.75 \mathrm{~m}, 19 \mathrm{~mm}$ bar spacing) was installed in front of the codend. To investigate the potential effect of light on the shrimp catches, a single LED dive light (Brinyte DIV01V, $21 \mathrm{~cm}$ long, 3.0-4.6 cm wide, $0.27 \mathrm{~kg}$ weight in seawater) with a $120^{\circ}$ beam angle, was mounted $6 \mathrm{~m}$ in front of the $8 \mathrm{~m}$ long grid section in the test trawl (Fig. 1). The distance from the torch to the bottom panel is determined by the number of meshes, the mesh openings and the shape of the belly transect. Assuming 30\% lateral mesh opening and a circular shape of the transect, the vertical distance would be $3.4 \mathrm{~m}$. The control trawl had no light. Lights of three different colours were used during 
Fig. 2. Measured spectral radiance of the torches used in the experiment. The green light has a peak at $520 \mathrm{~nm}$ (green curve, $\Lambda=522 \mathrm{~nm}$ ), the white light (orange curve) two peaks at 458 and $606 \mathrm{~nm}$, respectively $(\Lambda=588 \mathrm{~nm})$. The red light (red curve) has a peak at $635 \mathrm{~nm}(\Lambda=632 \mathrm{~nm})$. The figure shows measured spectral radiance after $3 \mathrm{~h}$ use (peak intensities at $7.7,5.0$ and $2.5 \mathrm{~mW} \cdot \mathrm{m}^{-2} \cdot \mathrm{nm}^{-1}$ for red, green and white, respectively). Colour definition followed specification 8 in https://physics.info/color/. [Colour online.]

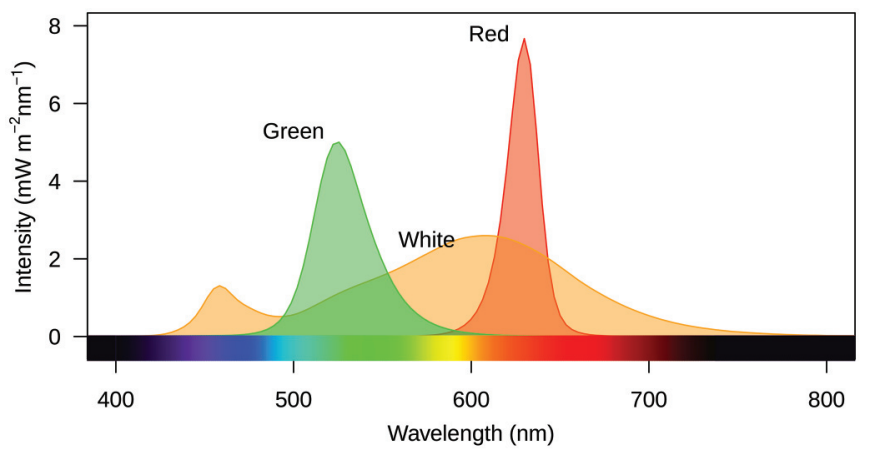

the trials: green (520 nm peak), red (635 nm peak) and white ( $\sim 430-750 \mathrm{~nm})$ (Fig. 2, intensities shown after $3 \mathrm{~h}$ of operation). The spectral radiances $\left(\mathrm{mW} \cdot \mathrm{m}^{-2} \cdot \mathrm{nm}^{-1}\right)$ for the lights were measured for over $12 \mathrm{~h}$ at $8{ }^{\circ} \mathrm{C}$. The intensity for the red light at $635 \mathrm{~nm}$ after $30 \mathrm{~min}$ (about the time from when the light was turned on until fishing started) was $18.0 \mathrm{~mW} \cdot \mathrm{m}^{-2}$, and fell to $7.7 \mathrm{~mW} \cdot \mathrm{m}^{-2}$ after $3 \mathrm{~h}$ and $2.8 \mathrm{~mW} \cdot \mathrm{m}^{-2}$ after $6 \mathrm{~h}$. From 6 to $12 \mathrm{~h}$, the intensity dropped linearly to $1.2 \mathrm{~mW} \cdot \mathrm{m}^{-2}$. The maximum intensity for the green light at $520 \mathrm{~nm}$ after $0.5 \mathrm{~h}$ was $7.2 \mathrm{~mW} \cdot \mathrm{m}^{-2}$ and dropped to $5.0 \mathrm{~mW} \cdot \mathrm{m}^{-2}$ after $3 \mathrm{~h}$ and $4.0 \mathrm{~mW} \cdot \mathrm{m}^{-2}$ after $6 \mathrm{~h}$. From 6 to $12 \mathrm{~h}$, the intensity fell linearly to $2.9 \mathrm{~mW} \cdot \mathrm{m}^{-2}$. The intensity for the white light at $606 \mathrm{~nm}$ after $30 \mathrm{~min}$ was $3.9 \mathrm{~mW} \cdot \mathrm{m}^{-2}$ and fell to 2.5 and $1.8 \mathrm{~mW} \cdot \mathrm{m}^{-2}$ after 3 and $6 \mathrm{~h}$ respectively. From 6 to $12 \mathrm{~h}$, the intensity dropped linearly from 1.8 to $1.3 \mathrm{~mW} \cdot \mathrm{m}^{-2}$. The total radiations for all wavelengths after $0.5,3,6$ and $12 \mathrm{~h}$ were $457,182,65$, and $29 \mathrm{~mW} \cdot \mathrm{m}^{-2}$ for red; 664,399 , 283 , and $200 \mathrm{~mW} \cdot \mathrm{m}^{-2}$ for white; and $307,212,169$, and $124 \mathrm{~mW} \cdot \mathrm{m}^{-2}$ for green light, respectively.

During the field experiments, one colour was tested at a time and the lights were alternated between the trawls (Table 1). The lights were fastened on both the trawls by means of frames made of PE plastic tubes and pointed forward towards the trawl opening (Fig. 3). They were cut with an inclination of $\sim 15^{\circ}$ so that the light tilted downwards. In front of the lights, $5 \mathrm{~cm}$ strips of silvery duct tape were adhered to increase light reflection. The light frames were kept on both the trawls to ensure they had the same position throughout the experiments and that the only difference between the different configurations was the light of the torches.

In each haul, the shrimp catches from the two codends were kept separated and weighed to the nearest kg after grating. Shrimp samples for length measurements were taken from each codend catch, aiming for samples sizes of $\sim 500$ specimens in every case. Digital calipers with an accuracy of $0.01 \mathrm{~mm}$ were used to measure carapace lengths. All measured lengths were rounded to the nearest $0.5 \mathrm{~mm}$ prior to analysis.

No in situ measurements of the ambient light intensity at the fishing depths were made during the experiment. However, measurements of light intensity were recorded during a hydrographic transect in the Skagerrak on 5 December 2018 with the RV G.M. Dannevig. These measurements were made with a Seabird PAR instrument, but the sensor did not allow for data resolution deeper than approximately $90 \mathrm{~m}$. Therefore, to estimate the light level at fishing depths of 170-350 m, we used the observed light intensity at $75 \mathrm{~m}$ and the extinction coefficient provided by Clarke and Wertheim (1956) for shelf water deeper than $90 \mathrm{~m}$ $(k=0.039)$. Measurements used for the calculations were recorded at position $58^{\circ} 08.05^{\prime} \mathrm{N}$ and $9^{\circ} 10.90^{\prime} \mathrm{E}$ at 10:24 UTC. The calculated light intensity ranged from $5.3 \times 10^{-4} \mathrm{~W} \cdot \mathrm{m}^{-2}$ at $170 \mathrm{~m}$ depth to $4.8 \times 10^{-6} \mathrm{~W} \cdot \mathrm{m}^{-2}$ at $350 \mathrm{~m}$.

\section{Data analyses}

The relative length-dependent efficiency of the test trawl compared to the control trawl, was estimated applying a polynomial logistic regression, based on the methods of Holst and Revill (2009). Alternatively, a generalized additive mixed model could be applied, or bootstrapping methods to account for the between haul variances. The choice of a parametric random effect model, however, allows for a simple way of testing formally the effects of explanatory variables (carapace length and light colour in our case).

A generalized linear mixed effect model (GLMM) with logistic link was applied. For investigating the effect of different light colours on length-dependent relative catch retention, using two identical trawls, the full model with a $k$-order polynomial is

(1) $\operatorname{logit}(\pi) \approx 0+\alpha_{1} \Lambda+\alpha_{2} \Lambda l+\beta_{0}+b+\beta_{1} l+\cdots+\beta_{k} l^{k}$

Here $\pi$ is the probability of shrimp of length $l$ being retained in the test trawl, giving that it was caught in one of the trawls. $o=$ $\log \left(q_{t} / q_{c}\right)$ is an offset, with $q_{\mathrm{t}}$ and $q_{\mathrm{c}}$ denoting the sampling proportions from the test and control catches, respectively. The $\alpha$ and $\beta$ values are the model parameters. The $b$ is the random effect at haul level, assumed to have mean of zero and be normally distributed, accounting for between-haul variation. $\Lambda$ is the mean wavelength, weighted with light intensity $I\left(\Lambda=\sum \lambda I / \sum I\right)$. The calculated means were 522, 588 and $632 \mathrm{~nm}$ for green, white and red light, respectively. A forward selection procedure was followed, with and without $\alpha_{1}$ and $\alpha_{2}$ in eq. 1, incrementing the polynomial order one at a time up to $k=4$, selecting the model with the lowest AIC $(-2 \times$ maximized log-likelihood $+2 \times$ number of parameters), counting the random effect as one parameter. The models were tested with and without lower order polynomials. Presented significance of terms are from deviance goodness-of-fit tests. Length-dependent relative catch ratio $r$ with the test trawl with light, given that both trawls catch equally, is derived from the relative catch $\pi$ :

$$
\text { (2) } r=\pi /(1-\pi)
$$

The relative catch ratio is more intuitive to comprehend as it describes proportional catch loss (or increase), and therefore added as separate plots (Fig. 4, middle panel). The confidence intervals are calculated as for ordinary regression models, treating the random effect as a nuisance parameter; $\operatorname{logit}(\pi) \pm 1.96 \times$ $\operatorname{SE}(\operatorname{logit}(\pi))$ (Hosmer and Lemeshow 2000; Zuur 2012). Standardized residuals were checked for normality and homogeneity. Models were then checked for over- or under-dispersion. The function gam in the mgcr package in R was used for the analysis (Wood 2017; R Core Team 2020).

\section{Results}

The small frames were easy to handle, and the plastic clamps facilitated quick insertion and removal of the lights. In all cases, the lights were on and with bright illumination at the end of the tows. A total of 29714 shrimp were measured from 28 valid hauls, 11 with green (seven starboard, four port), eight with white (four starboard, four port) and nine with red light (six starboard, three port). White and red lights were used alternately the first eight days, before the green light was added to the series. Average haul duration was $10.4 \mathrm{~h}$ and fishing depths varied from 170 to $315 \mathrm{~m}$. Shrimp catches in individual hauls ranged from 121 to $662 \mathrm{~kg}$ per trawl (Table 1). Towing speed was $\sim 0.8 \mathrm{~m} \cdot \mathrm{s}^{-1}$ (1.6 knots). 
Table 1. Haul sequence, setting time (UTC), tow duration, arrangement of lights, shrimp catches and sampling rates for each haul.

\begin{tabular}{|c|c|c|c|c|c|c|c|c|c|}
\hline \multirow[b]{2}{*}{ Haul No. } & \multicolumn{2}{|l|}{ Tow start } & \multicolumn{2}{|c|}{ Catch (kg) } & \multirow[b]{2}{*}{$\begin{array}{l}\text { Light } \\
\text { (colour) }\end{array}$} & \multirow[b]{2}{*}{$\begin{array}{l}\text { Light (port, } \\
\text { starboard) }\end{array}$} & \multirow[b]{2}{*}{$\begin{array}{l}\text { Tow } \\
\text { time (h) }\end{array}$} & \multicolumn{2}{|c|}{ Sampling rates $\left(\mathrm{kg} \cdot \operatorname{trawl}^{-1}\right)$} \\
\hline & $\begin{array}{l}\text { Date } \\
\text { (dd.mm) }\end{array}$ & $\begin{array}{l}\text { Time } \\
\text { (hh:mm) }\end{array}$ & $\begin{array}{l}\text { With } \\
\text { light }\end{array}$ & $\begin{array}{l}\text { Without } \\
\text { light }\end{array}$ & & & & $\begin{array}{l}\text { With } \\
\text { light }\end{array}$ & $\begin{array}{l}\text { Without } \\
\text { light }\end{array}$ \\
\hline 1 & 17.11 & $00: 47$ & 570 & 662 & Red & Starboard & 13.9 & 0.005122 & 0.003557 \\
\hline 2 & 17.11 & $18: 13$ & 338 & 469 & White & Starboard & 14.1 & 0.008689 & 0.005795 \\
\hline 3 & 18.11 & 09:51 & 314 & 350 & Red & Port & 7.3 & 0.008401 & 0.007931 \\
\hline 4 & 18.11 & $18: 12$ & 344 & 502 & White & Port & 5.8 & 0.008839 & 0.005746 \\
\hline 5 & 20.11 & 03:00 & 172 & 156 & Red & Starboard & 8.0 & 0.019221 & 0.015481 \\
\hline 6 & 20.11 & 12:08 & 415 & 391 & White & Starboard & 9.7 & 0.007386 & 0.006354 \\
\hline 7 & 21.11 & 01:24 & 320 & 262 & Red & Port & 8.8 & 0.008214 & 0.010786 \\
\hline 8 & 21.11 & 11:09 & 344 & 307 & White & Port & 8.9 & 0.009493 & 0.008230 \\
\hline 9 & 21.11 & $20: 58$ & 543 & 545 & White & Starboard & 13.5 & 0.005804 & 0.006011 \\
\hline 10 & 24.11 & $06: 53$ & 194 & 178 & Red & Starboard & 9.6 & 0.013335 & 0.016303 \\
\hline 11 & 24.11 & $18: 41$ & 309 & 304 & White & Port & 13.0 & 0.009921 & 0.010966 \\
\hline 12 & 25.11 & 09:31 & 231 & 296 & Green & Starboard & 7.4 & 0.012548 & 0.009269 \\
\hline 13 & 25.11 & $18: 03$ & 364 & 355 & Green & Port & 6.0 & 0.008402 & 0.007766 \\
\hline 14 & 27.11 & $04: 40$ & 290 & 323 & Green & Starboard & 7.4 & 0.010626 & 0.006375 \\
\hline 15 & 27.11 & $13: 14$ & 264 & 220 & Red & Starboard & 11.8 & 0.011635 & 0.014052 \\
\hline 16 & 28.11 & 03:34 & 201 & 204 & Green & Starboard & 11.5 & 0.014747 & 0.015570 \\
\hline 17 & 28.11 & 16:04 & 269 & 260 & Red & Port & 11.9 & 0.009665 & 0.010253 \\
\hline 18 & 29.11 & $04: 43$ & 264 & 282 & Green & Port & 13.3 & 0.010594 & 0.011320 \\
\hline 19 & 30.11 & 09:35 & 133 & 150 & Red & Starboard & 11.9 & 0.010499 & 0.009363 \\
\hline 20 & 30.11 & $23: 18$ & 161 & 168 & Green & Starboard & 12.7 & 0.021517 & 0.020062 \\
\hline 21 & 01.12 & $13: 23$ & 161 & 271 & Green & Port & 10.6 & 0.025841 & 0.013635 \\
\hline 22 & 02.12 & 01:02 & 269 & 254 & Red & Starboard & 10.0 & 0.012793 & 0.013145 \\
\hline 23 & 02.12 & $12: 15$ & 336 & 458 & Green & Starboard & 11.8 & 0.009356 & 0.006782 \\
\hline 24 & 03.12 & 23:08 & 137 & 153 & Green & Starboard & 12.8 & 0.016737 & 0.018203 \\
\hline 25 & 04.12 & $13: 12$ & 300 & 272 & White & Starboard & 11.9 & 0.011874 & 0.011329 \\
\hline 26 & 05.12 & 09:14 & 256 & 358 & Green & Port & 9.7 & 0.010242 & 0.007301 \\
\hline 27 & 05.12 & 20:06 & 121 & 231 & White & Port & 10.1 & 0.026291 & 0.011656 \\
\hline 28 & 06.12 & 07:27 & 286 & 318 & Green & Starboard & 12.3 & 0.014208 & 0.012389 \\
\hline
\end{tabular}

Fig. 3. The plastic frames that were mounted on each trawl. Plastic clamps were used to facilitate easy changing of torch lights. Strips of silvery duct tape $(5 \mathrm{~cm}$ wide) were adhered in front of the torches to increase light reflection. The lights are $21 \mathrm{~cm}$ long and $3.0-4.6 \mathrm{~cm}$ in diameter.

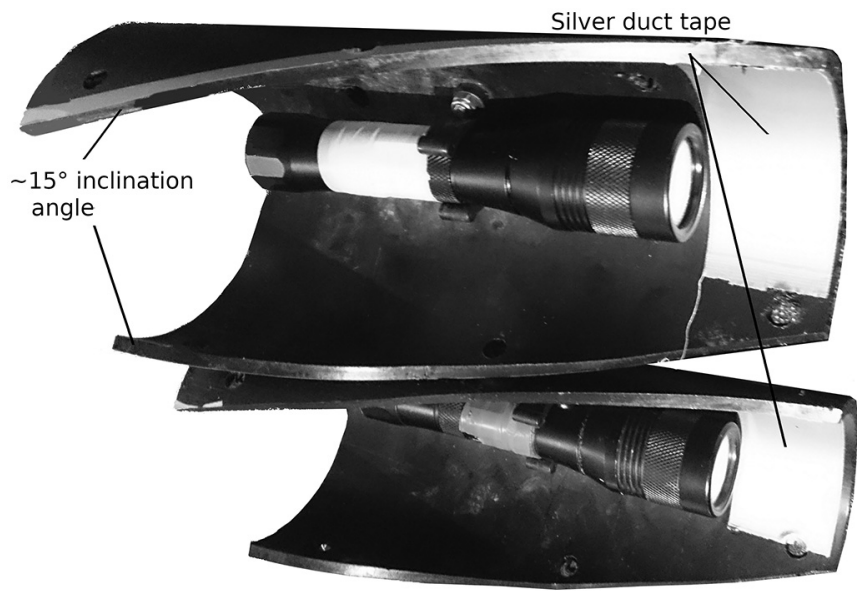

Best fit of the regression model was obtained for a second-order polynomial model with significant effects of carapace length and light colour (Table 2):

$$
\operatorname{logit}(\pi) \sim \beta_{0}+\alpha_{1} \Lambda+\alpha_{2} l \Lambda+\beta_{1} l+\beta_{2} l^{2}+b_{0}
$$

The dispersion parameter $D$ for the presented model was estimated at 1.4, i.e., some overdispersion present. The residual inspection, however, did not reveal any indications of model mismatch. The data were thus fitted with a quasibinomial link to account for the overdispersion.

The modelled relative catch retention and catch ratio (Fig. 4; Table 3) showed increasing catch loss with decreasing shrimp size when light was used for all the light sources tested, but the pattern differed significantly between the three light sources $\left(\chi^{2}=12.1, \mathrm{df}=2, p=0.002\right)$. The red light caused the least reduction, and significant loss was observed for shrimp sizes below $17.5 \mathrm{~mm}$ CL. For white light, the catch loss was significant for shrimp below $19.5 \mathrm{~mm}$ CL. Green light yielded the greatest reduction with significant loss for shrimp below $20.8 \mathrm{~mm}$ CL. These upper size limits for catch loss of shrimp were read from the estimated upper confidence limits in Fig. 4 (upper panel). For all the three comparative fishing experiments, the smallest shrimps had carapace lengths of $10 \mathrm{~mm}$ (Fig. 4, lower panel).

\section{Discussion}

This study demonstrated that artificial light installed at the rear end of the trawl's belly increased the escape of small shrimp compared to an identical trawl without light. The relative escape increased with decreasing shrimp length and differed significantly between light colours.

The side and top panels were constructed of larger meshes (200 $\mathrm{mm}$ in front decreasing to 50 in the aft belly) than the bottom panel $(40 \mathrm{~mm})$, and if selection took place through the former panels, a loss of large shrimp ( $>20 \mathrm{~mm} \mathrm{CL}$ ) would have been expected. This was not the case. The escape of shrimp was most likely through the bottom panel of the trawl. Catch loss has been associated with increased mesh size in the bottom panel of a shortened shrimp trawl (Ingólfsson and Jørgensen 2020). The size of the escaped shrimp conforms with that of the aforementioned 
Fig. 4. Top panel: Observed (circles) and modeled (lines) relative catch retention. Middle panel: Relative catch ratio $(r$; eq. 2 ) for the experimental trawl as function of shrimp size (carapace length). All measured shrimp are included in the analyses, yet the catch retention curves and confidence limits are restricted to lengths found in at least half the hauls. The coloured areas illustrate pointwise 95\% confidence limits for the modeled curves. The broken horizontal lines on the top and middle plots indicate equal catches in the test and control trawls. Where the confidence limits are below the broken lines, catch loss is significant $(p<0.05)$. Bottom panel: Size distributions of catches in control and experimental trawls with red, white and green lights, respectively. The dotted vertical lines indicate the limits for undersized shrimp (below 15 mm carapace length (CL)) and the most valuable cooked shrimp (above $20 \mathrm{~mm} \mathrm{CL}$ ). Shrimp below $20 \mathrm{~mm}$ CL is landed raw for peeling. The $y$ axis for the size distribution is on a square-root scale. [Colour online.]

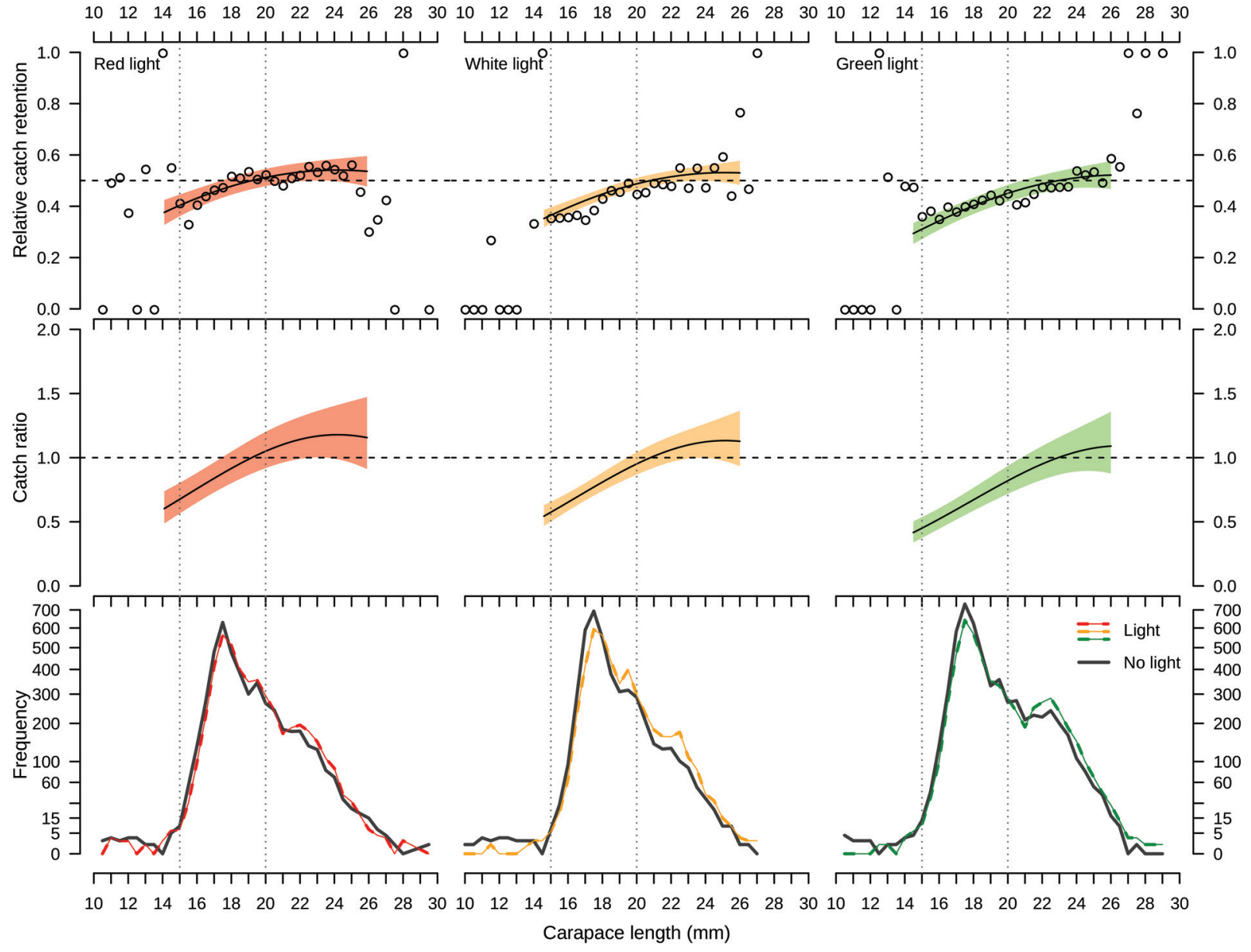

Table 2. AIC results, showing the linear components of the logistic models tested for relative length-dependent catch efficiency due to the presence of artificial lights.

\begin{tabular}{lll}
\hline Model ID & Model & AIC \\
\hline 0 & $\beta_{0}+b$ & 3594.7 \\
1 & $\beta_{0}+b+\beta_{1} l$ & 3412.3 \\
2 & $\beta_{0}+b+\beta_{1} l+\alpha_{1} \Lambda$ & 3408.2 \\
3 & $\beta_{0}+b+\beta_{1} l+\alpha_{1} \Lambda+\alpha_{2} l \Lambda$ & 3405.4 \\
4 & $\beta_{0}+b+\beta_{1} l+\beta_{2} l^{2}$ & 3403.9 \\
5 & $\beta_{0}+b+\beta_{1} l+\beta_{2} l^{2}+\alpha_{1} \Lambda$ & 3400.0 \\
6 & $\beta_{0}+b+\beta_{1} l+\beta_{2} l^{2}+\alpha_{1} \Lambda+\alpha_{2} l \Lambda$ & 3395.4 \\
7 & $\beta_{0}+b+\beta_{1} l+\beta_{2} l^{2}+\beta_{3} l^{3}$ & 3403.6 \\
8 & $\beta_{0}+b+\beta_{1} l+\beta_{2} l^{2}+\beta_{3} l^{3}+\alpha_{1} \Lambda$ & 3399.7 \\
9 & $\beta_{0}+b+\beta_{1} l+\beta_{2} l^{2}+\beta_{3} l^{3}+\alpha_{1} \Lambda+\alpha_{2} l \Lambda$ & 3395.2 \\
10 & $\beta_{0}+b+\beta_{1} l+\beta_{2} l^{2}+\beta_{3} l^{3}+\beta_{4} l^{4}$ & 3405.6 \\
11 & $\beta_{0}+b+\beta_{1} l+\beta_{2} l^{2}+\beta_{3} l^{3}+\beta_{4} l^{4}+\alpha_{1} \Lambda$ & 3401.6 \\
12 & $\beta_{0}+b+\beta_{1} l+\beta_{2} l^{2}+\beta_{3} l^{3}+\beta_{4} l^{4}+\alpha_{1} \Lambda+\alpha_{2} l \Lambda$ & 3397.2 \\
\hline
\end{tabular}

Note: Polynomial models with carapace length (l) up to fourth order were tested, with wavelength $(\Lambda)$ as explanatory variable for intercept and slope (carapace length). The difference in AIC between the second- and third-order models (model ID 6 and 9 ) is only 0.2 and the more parsimonious second-order model thus chosen.
Table 3. Results from the quasibinomial, polynomial generalized linear mixed effect models (GLMM) for the effect of light wavelengths $(\Lambda)$ on length-dependent shrimp catch retention (see eq. 1).

\begin{tabular}{|c|c|c|c|c|}
\hline Parameter & Explanatory variable & Estimate & SE & $p$ \\
\hline$\beta_{0}$ & Intercept & -8.765 & 1.947 & $<0.001$ \\
\hline$\beta_{1}$ & Length & 0.501 & 0.128 & $<0.001$ \\
\hline$\beta_{2}$ & Length $^{2}$ & -0.0066 & 0.0023 & $<0.005$ \\
\hline$\alpha_{1}$ & Wavelength & 0.00803 & 0.0028 & $<0.005$ \\
\hline$\alpha_{2}$ & Wavelength $\times$ Length & -0.0029 & 0.0001 & $<0.05$ \\
\hline$\sigma_{0}$ & Random effect (Intercept) & 0.222 & 一 & $<0.001$ \\
\hline
\end{tabular}

study, using $40 \mathrm{~mm}$ mesh sizes. Observations on the vertical distribution of northern shrimp have shown that the biomass is densest close to the seabed, although they perform some vertical migration (Barr 1970). Using a demersal trawl with a headline height of 6-7 m, De Louche et al. (2006) caught about 90\% of the biomass closer than $4 \mathrm{~m}$ from the bottom. Similarly, Larsen et al. (1993) caught more than 50\% of the shrimp biomass closer than $2 \mathrm{~m}$ from the bottom with an $8 \mathrm{~m}$ tall sampling frame. The trawls in our experiment had headline heights of about $19 \mathrm{~m}$ and at the position of the light, the bottom panel is 7-9 $\mathrm{m}$ off the seabed. It 
is therefore reasonable to assume that most shrimp were passing along the oblique bottom panel when they reached the area where the light was mounted.

The lights can be interpreted by the shrimp as an unknown danger, triggering an anti-predatory response (Domenici 2002). Two alternative behavioural responses to the light stimuli can explain the observed escape; either the light immobilized the shrimp, or an active escape response was evoked. During underwater filming in front of a trawl, applying artificial white light, northern shrimp remained passive and were run over by the trawl (E. Hreinsson, Marine and Freshwater Research Institute, Iceland, personal communication). On the other hand, in close proximity to an approaching green laser beam, shrimp avoided the beam by jumping (E. Hreinsson, personal communication). Assuming the response is to remain passive, the shrimp can be considered as drifting particles of different sizes, and the approaching inclined panel with open meshes acts as a filtering device. Without the light stimuli, the shrimp may to a larger extent move actively to avoid the bottom panel. If the light triggers an active escape response to the light, the shrimp will likely seek towards the seabed or away from the light, bringing them into contact with the bottom panel where the smaller specimens can escape. Whether the response is an instance of negative phototaxis or a more general threat avoidance response cannot be discerned given the experimental setup (see Melli et al. 2018).

Size selection was obtained with all the three light colours tested. Across the range of size groups for which catch loss was observed, the green light resulted in the strongest escape response, and red the weakest. Crustaceans are known to have strongest spectral sensitivity towards green light $\sim 500 \mathrm{~nm}$ (Frank and Widder 1999; Johnson et al. 2002). Males of northern shrimp with carapace lengths below $20 \mathrm{~mm}$ have a mean spectral sensitivity peak of $510 \mathrm{~nm}$ (Eaton 1972). The spectral sensitivity above $520 \mathrm{~nm}$ is not known. For Pandalus montagui and Nephrops norvegicus, crustaceans often caught along with northern shrimp, spectral sensitivity at $600 \mathrm{~nm}$ is $10 \%-15 \%$ of the maximum sensitivity observed at $519 \mathrm{~nm}$ (Johnson et al. 2002). The same spectral range and sensitivity is likely to apply for northern shrimp. This could explain the response towards the red light applied in our study, which emits light with wavelengths in the orange field down to $\sim 590 \mathrm{~nm}$. For the visible spectrum, light absorption increases with wavelength, and at $600 \mathrm{~nm}$ absorption per $\mathrm{m}$ is about 11-fold that at $500 \mathrm{~nm}$, resulting in light of shorter wavelengths travelling significantly farther in water than light of longer wavelengths (Pope and Fry 1997). To put things into perspective, with the same intensities of red (600 $\mathrm{nm}$ wavelength) and green (500 nm wavelength) light, the animal is likely to observe green light as 100 times more intense than the red at a distance of $1 \mathrm{~m}$ from the light source. In addition, due to the differences in absorption, the relative difference increases 11-fold for every additional $1 \mathrm{~m}$ distance. Therefore, while the total radiation for the different lights varied between light colours and over time $\left(0.46-0.03 \mathrm{~W} \cdot \mathrm{m}^{-2}\right.$ for red, $0.66-0.20 \mathrm{~W} \cdot \mathrm{m}^{-2}$ for white and $0.31-0.12 \mathrm{~W} \cdot \mathrm{m}^{-2}$ for green from 0.5 to $12 \mathrm{~h}$ use), the between-colour variations in light intensity are likely insignificant as regards the perceived visibility to the shrimp. Also, while a less marked escape reaction was observed towards the red light than those of shorter wavelengths, it is noteworthy that with the relatively low light intensities within the animal's presumed spectral sensitivity range (up to $\sim 600 \mathrm{~nm}$ ), and lesser area coverage due to greater absorption of the longer wavelengths, the response towards the red light was still significant. Therefore, by applying green lights, the light intensity can probably be significantly reduced and still cause the behavioural response.

Due to the possibility of damaging the eye cells of deep living organisms (Nilsson and Lindström 1983; Shelton et al. 1985; Meyer-Rochow 2001), light levels and exposure time need consideration. While the light intensities in this study of $<0.5 \mathrm{~W} \cdot \mathrm{m}^{-2}$ were in great contrast to the darkness in the deep, they are unlikely to cause permanent damage to the shrimp eyes. In addition, their placement in the top panel, distanced from shrimp passing along the lower part of trawl, render eye damages unlikely. However, while placing a light of similar intensity in the codend itself could yield comparable results, such a location could cause permanent eye damages to shrimps that escape after being exposed to proximity of the light for extended period of time.

The employed LED dive torches used batteries as a power source, and for long hauls, battery lifetime becomes an issue. Further, when choosing wavelengths, the maximum spectral sensitivity of the species and light absorption need consideration. Having chosen wavelengths with high spectral sensitivity for the shrimp, light intensity can be reduced to extend battery life or alternative torches with longer battery life explored. In the present study, all the lights appeared to shine with bright lights at the end of all tows. Still the laboratory measurements showed that the spectral intensity of red, white and green light after $12 \mathrm{~h}$ of operation had been reduced to $6.5 \%, 30.3 \%$ and $38.7 \%$, respectively, of the spectral intensities after $0.5 \mathrm{~h}$ of operation, Thus, the torches with green light both provide the light with maximum spectral sensitivity to shrimp and maintain the highest proportion of the initial spectral intensity after $12 \mathrm{~h}$ of operation. Compared to the lowest spectral intensity of $0.03 \mathrm{~W} \cdot \mathrm{m}^{-2}$ after $12 \mathrm{~h}$ of operation (the red torch), the ambient light intensity at the fishing depth was estimated at $5.3 \times 10^{-4} \mathrm{~W} \cdot \mathrm{m}^{-2}$ at $170 \mathrm{~m}$ depth to $4.8 \times 10^{-6} \mathrm{~W} \cdot \mathrm{m}^{-2}$ at $350 \mathrm{~m}$. All the torches should therefore yield marked contrast to the ambient light level at the fishing depths, as suggested by a behavioural response of shrimp to all the light sources tested.

The two identical light frames were kept on both trawls throughout the experiments. This was done to eliminate a possible effect of the light frames themselves on shrimp behaviour. The frames were mounted on the outside of the trawl, with the narrower part pointing forward to minimize drag. The torches were mounted sheltered inside the plastic frames, and we consider it unlikely that the absence/presence of the small, lightweight $(0.27 \mathrm{~kg}$ weight in seawater) torch housing itself influenced displacement of water inside the rear end of the trawl's belly.

Earlier studies have shown that different types of lights can alter shrimp behaviour (Nguyen and Winger 2019). For bottom trawls specifically, LED lights placed along the fishing line in a trawl resulted in a reduction of the bycatch of several fish species without loss of the target species, Pandalus jordani (Hannah et al. 2015). A commercial northern shrimp trawler, fishing in the Barents Sea, tested the same type of LED lights placed alternately along the fishing lines and headlines of three trawls simultaneously. The results showed no reduction in bycatch but a large loss of shrimp (R. Larsen, The Arctic University of Norway, personal communication). The latter study suggest that the lights should be distanced from the trawl opening to avoid loss of northern shrimp beneath or above the trawl. In our study, the decision to position the lights in the top panel rather than in the bottom panel was based on earlier observations using light in combination with underwater cameras. In 2017, we conducted a study, comparing a regular trawl to a short one. In three out of 11 hauls, a camera with the same red light as tested in this study was placed in the same position, $32 \mathrm{~m}$ behind the fishing line. No observations of shrimp movement or behaviour could be made, but the selectivity results from these hauls with light deviated significantly, with less catch retention of small shrimp, compared to the remaining eight hauls (Ó. Ingólfsson and T. Jørgensen, unpublished). If the lights elicit active escape response, placing lights at the bottom panel or in the codend itself are possible alternatives, but mud clouds generated by the ground gear rise from the bottom in a short time, reducing visibility. Attempts to film codends on muddy shrimp grounds become in many cases unsuccessful (Ó. Ingólfsson, personal observation; Dellapenna et al. 2006). However, placing the 
lights in the upper panel, distanced from the trawl opening, should keep the light above the cloud. In addition, it is a position in the rear end of the trawl funnel, where the passage is reasonably narrow $(3.4 \mathrm{~m}$; Fig. 2) so that the lights should be visible to most passing shrimp.

To effectively use light to size-select northern shrimp, both the escape opportunities for the animal and the light source characteristics and placement need consideration. The meshes need to be open and of a mesh size suitable for releasing small, unwanted specimen, while retaining the larger commercial-sized shrimp. Shortening of the trawl belly results in more open meshes in this section of the trawl, which in turn can enhance escape (Broadhurst et al. 2012; Ingólfsson and Jørgensen 2020). Compared to the standard commercial trawl design, this trawl has a shorter body with steeper cutting rate and its bottom panel therefore slants at a higher angle. This shorter body presumably results in more open meshes in the bottom panel of the experimental trawl, while the steeper panel increases the contact probability of shrimp with the panel as the shrimps move through the belly towards the codend. Consequently, one would expect the lights to have a more pronounced effect on size selectivity in this trawl than in the standard trawl. Thus, in combination with choice of mesh size, the behavioural response due to the presence of light resulted in size selection that can be used to reduce catch retention of undersized shrimp.

The results show that application of a simple and cost-effective solution like light can improve size selectivity in the northern shrimp fishery. By using lights that meet the spectral sensitivity of the shrimp and combining the light avoidance response of northern shrimp with the appropriate mesh size in the trawl, release of undersized shrimp can be significantly improved. For the application of lights to be considered by fisheries managers, a standardised solution needs to be available for observers to control. A permitted light source should preferably emit constant light intensity over a period corresponding to the maximum haul duration of commercial vessels. Also, a solution for sufficient mesh openings in the proximity of the light needs to be specified. As this is technically attainable, we consider the application of lights for reducing catches of undersized shrimp to be a real option.

\section{Funding statement}

This study was co-financed by The Norwegian Seafood Research Fund (FHF, grant No. 901303, "Optimization of Fishing with Shrimp Trawls 2016-2019”).

\section{Acknowledgements}

We thank our co-worker Trude Hauge Thangstad, skipper Frode Jensen and his crew on F/V Tempo, and Peder Asbjørn Pedersen at the Skagerak trål og notbøteri AS net-loft for invaluable assistance during all stages of this study.

\section{References}

Anonymous. 2005. Regulations on exercising sea-water fisheries. [Forskrift om utøvelse av fiske i sjøen.]. [In Norwegian.] Available from https://lovdata. no/dokument/SF/forskrift/2004-12-22-1878.

Barr, L. 1970. Diel vertical migration of Pandalus borealis in Kachemak Bay. J. Fish. Res. Bd. Can. 27(4): 669-676. doi:10.1139/f70-071.

Broadhurst, M.K., Millar, R.B., Kennelly, S.J., Macbeth, W.G., Young, D.J., and Gray, C.A. 2004. Selectivity of conventional diamond- and novel squaremesh codends in an Australian estuarine penaeid-trawl fishery. Fish. Res. 67: 183-194. doi:10.1016/j.fishres.2003.09.043.

Broadhurst, M.K., Sterling, D.J., and Millar, R.B. 2012. Short vs long penaeid trawls: effects of side taper on engineering and catching performances. Fish. Res. 134-136: 73-81. doi:10.1016/j.fishres.2012.08.009.

Broadhurst, M.K., Sterling, D.J., and Millar, R.B. 2015. Effects of diel period and diurnal cloud cover on the species selection of short and long penaeid trawls. Fish. Res. 170: 144-151. doi:10.1016/j.fishres.2015.05.027.

Campos, A., Fonseca, P., and Erzini, K. 2002. Size selectivity of diamond and square mesh cod ends for rose shrimp (Parapenaeus longirostris) and
Norway lobster (Nephrops norvegicus) off the Portuguese south coast. Fish. Res. 58: 281-301. doi:10.1016/S0165-7836(01)00396-4.

Clarke, G.L., and Wertheim, G.K. 1956. Measurements of illumination at great depths and at night in the Atlantic Ocean by means of a new bathyphometer. Deep-Sea Res. 3: 189-205. doi:10.1016/0146-6313(56)90003-X.

Conolly, P.C. 1993. Bycatch activities in Brazil. In International Conference on Shrimp By-Catch, May 24-27, 1992. Edited by R.P. Jones. Southeastern Fisheries Association, Tallahassee, Fla., USA. pp. 291-302.

Cronin, T.W., and Douglas, R.H. 2014. Seeing and doing: how vision shapes animal behaviour. Philos. Trans. R Soc. B Biol. Sci. 369: 20130030. doi:10.1098/ rstb.2013.0030. PMID:24395959.

Dellapenna, T.M., Allison, M.A., Gill, G.A., Lehman, R.D., and Warnken, K.W. 2006. The impact of shrimp trawling and associated sediment resuspension in mud dominated, shallow estuaries. Estuar. Coastal Shelf Sci. 69(3-4): 519-530. doi:10.1016/j.ecss.2006.04.024.

De Louche, H., Hiscock, W., Legge, G., Chidley, G., and Spence, D. 2006. An experiment to determine the vertical distribution of northern shrimp in the lower water column using a multi level trawl. Centre for Sustainable Aquatic Resources, Fisheries and Marine Institute of Memorial University of Newfoundland, Canada. CSAR P-117 \& P-159.

Domenici, P. 2002. The visually mediated escape response in fish: predicting prey responsiveness and the locomotor behaviour of predators and prey. Mar. Freshw. Behav. Physiol. 35(1-2): 87-110. doi:10.1080/10236240290025635.

Eaton, P.B. 1972. A comparative study of the photoreceptors of the decapod crustacean Pandalus borealis, Krøyer. Ph.D. thesis, Dalhousie University, Halifax, Nova Scotia.

Eaton, P.B., and Boyd, C.M. 1970. Photoreception in the nauplius eye of Pandalus borealis Kröyer: Decapoda, Crustacea. Can. J. Zool. 48(1): 119-121. doi:10.1139/ z70-014.

Frank, T.M., and Widder, E.A. 1999. Comparative study of the spectral sensitivities of mesopelagic crustaceans. J. Comp. Physiol. A, 185: 255-265. doi:10.1007/s003590050385

Frank, T.M., Johnsen, S., and Cronin, T.W. 2012. Light and vision in the deep-sea benthos: II. Vision in deep-sea crustaceans. J. Exp. Biol. 215: 33443353. doi:10.1242/jeb.072033. PMID:22956247.

Garcia, E.G. 2007. The northern shrimp (Pandalus borealis) offshore fishery in the Northeast Atlantic. Adv. Mar. Biol. 52: 147-266. doi:10.1016/S0065-2881 (06)52002-4. PMID:17298891.

Gaten, E. 1988. Light-induced damage to the dioptric apparatus of Nephrops norvegicus (L.) and the quantitative assessment of the damage. Mar. Behav. Physiol. 13(2): 169-183. doi:10.1080/10236248809378671.

Gillett, R. 2008. Global study of shrimp fisheries. FAO Fish. Tech. Pap. 475

Grimaldo, E. 2006. The effects of grid angle on a modified Nordmøre-grid in the Nordic Shrimp Fishery. Fish. Res. 77: 53-59. doi:10.1016/j.fishres.2005.09.001.

Hannah, R.W., and Jones, S.A. 2003. Measuring the height of the fishing line and its effect on shrimp catch and bycatch in an ocean shrimp (Pandalus jordani) trawl. Fish. Res. 60: 427-438. doi:10.1016/S0165-7836(02)00138-8.

Hannah, R.W., Lomeli, M.J., and Jones, S.A. 2015. Tests of artificial light for bycatch re-duction in an ocean shrimp (Pandalus jordani) trawl: strong but opposite effects at the footrope and near the bycatch reduction device. Fish. Res. 170: 60-67. doi:10.1016/j.fishres.2015.05.010.

He, P., and Balzano, V. 2007. Reducing the catch of small shrimps in the Gulf of Maine pink shrimp fishery with a size-sorting grid device. ICES J. Mar. Sci. 64: 1551-1557. doi:10.1093/icesjms/fsm098.

High, W.L., Ellis, I.E., and Lusz, L.D. 1969. A progress report on the development of a shrimp trawl to separate shrimp from fish and bottom-dwelling animals. Comm. Fish. Rev. 31: 20-33.

Holst, R., and Revill, A. 2009. A simple statistical method for catch comparison studies. Fish. Res. 95: 254-259. doi:10.1016/j.fishres.2008.09.027.

Hosmer, D.W., and Lemeshow, S. 2000. Applied logistic regression. 2nd ed. John Wiley \& Sons, Danvers. 375 pp. doi:10.1002/0471722146.

Ingólfsson, Ó.A., and Jørgensen, T. 2020. Shorter trawls improve size selection of northern shrimp. Can. J. Fish. Aquat. Sci. 77(1): 202-211. doi:10.1139/ cjfas-2018-0443.

Isaksen, B., Valdemarsen, J.W., Larsen, R.B., and Karlsen, L. 1992. Reduction of fish by-catch in shrimp trawl using a rigid separator grid in the aft belly. Fish. Res. 13: 335-352. doi:10.1016/0165-7836(92)90086-9.

Johnson, M.L.P., Gaten, E., and Shelton, P.M.J. 2002. Spectral sensitivities of marine decapods crustaceans and a review of spectral sensitivity variation in relation to habitat. J. Mar. Biol. Assoc. U.K. 82: 835-842. doi:10.1017| S0025315402006203.

Kelleher, K. 2005. Discards in the world's marine fisheries. An update. FAO Fisheries Technical Paper No. 470. FAO, Rome.

Larsen, R.B., Kristjansson, J., and Marteinsson, J.E. 1993. Vertical size distribution of shrimps (Pandalus borealis) in the water column 0 to $8 \mathrm{~m}$ off the seabed. ICES Mar. Sci. Symp. 196: 207-210.

Larsen, R.B., Herrmann, B., Sistiaga, M., Brinkhof, J., Tatone, I., and Langård, L. 2017. Performance of the Nordmøre grid in shrimp trawling and potential effects of guiding funnel length and light stimulation. Mar. Coast. Fish. 9: 479-492. doi:10.1080/19425120.2017.1360421.

Larsen, R.B., Sistiaga, M., Herrmann, B., Brinkhof, J., Tatone, I., and Santos, J. 2018a. The effect of Nordmøre grid length and angle on codend entry of bycatch fish species and shrimp catches. Can. J. Fish. Aquat. Sci. 76(2): 1-12. doi:10.1139/cjfas-2018-0069. 
Larsen, R.B., Herrmann, B., Sistiaga, M., Brinkhof, J., and Grimaldo, E. $2018 b$. Bycatch reduction in the Norwegian Deep-water Shrimp (Pandalus borealis) fishery with a double grid selection system. Fish. Res. 208: 267-273. doi:10. 1016/j.fishres.2018.08.007.

Melli, V., Krag, L.A., Herrmann, B., and Karlsen, H. 2018. Investigating fish behavioural responses to LED lights in trawls and potential applications for bycatch reduction in the Nephrops-directed fishery. ICES J. Mar. Sci. 75(5): 1682-1692. doi:10.1093/icesjms/fsy048.

Meyer-Rochow, V. 2001. The crustacean eye: dark/light adaptation, polarization sensitivity, flicker fusion frequency, and photoreceptor damage. Zool. Sci. 18(9): 1175-1197. doi:10.2108/zsj.18.1175. PMID:11911074.

Nguyen, K.Q., and Winger, P.D. 2019. Artificial light in commercial industrialized fishing applications: a review. Rev. Fish. Sci. Aquac. 27(1): 106-126. doi:10.1080/23308249.2018.1496065.

Nilsson, H.L., and Lindström, M. 1983. Retinal damage and sensitivity loss of a light-sensitive crustacean compound eye (Cirolina borealis): electron microscopy and electrophysiology. J. Exp. Biol. 107: 277-292. doi:10.1242/jeb.107.1.277.

Polet, H. 2000. Codend and whole trawl selectivity of a shrimp beam trawl used in the North Sea. Fish. Res. 48: 167-183. doi:10.1016/S0165-7836(00)00125-9.

Pope, R.M., and Fry, E.S. 1997. Absorption spectrum $\sim 380-700 \mathrm{~nm}$ of pure water. II. Integrating cavity measurements. Appl. Opt. 36(33): 8710-8723. doi:10.1364/AO.36.008710. PMID:18264420.
R Core Team. 2020. R: a language and environment for statistical computing. R Foundation for Statistical Computing, Vienna, Austria. Available from https://www.R-project.org/.

Shelton, P.M.J., Gaten, E., and Chapman, C.J. 1985. Light and retinal damage in Nephrops norvegicus (L.) (Crustacea). Proc. R. Soc. B Biol. Sci. 226: 217236. doi:10.1098/rspb.1985.0092.

Southworth, L.K., Ratcliffe, F.C., Bloor, I.S.M., Emmerson, J., Watson, D., Beard, D., and Kaiser, M.J. 2020. Artificial light improves escapement of fish from a trawl net. J. Mar. Biol. Assoc. 100: 267-275. doi:10.1017| S0025315420000028.

Thorsteinsson, G. 1981. The effect of net slack in the side panels of shrimp trawls on the size distribution of the catch. ICES CM 1981/B:5.

Thorsteinsson, G. 1992. The use of square mesh codends in the Icelandic shrimp (Pandalus borealis) fishery. Fish. Res. 13(3): 255-266. doi:10.1016/01657836(92)90080-D.

Wardle, C.S. 1993. Fish behavior and fishing gear. In Behavior of teleost fishes. Edited by T.J. Pitcher. Chapman and Hall, London. pp. 609-643.

Wood, S.N. 2017. Generalized additive models: an introduction with R. 2nd ed. Chapman and Hall/CRC.

Zuur, A.F. 2012. A beginner's guide to general additive models with R. Highland Statistics Limited. 